\title{
Tourism Policy in Jamaica: A Tale of Two Governments
}

\section{Donna Chambers}

Faculty of Leisure and Tourism, Buckinghamshire Chilterns University College, High Wycombe HP13 5BB

\section{David Airey}

School of Management Studies for the Service Sector, University of Surrey, Guildford, Surrey GU2 5XH

This paper explores the role of public policy in the development of tourism in Jamaica. It focuses on two separate and contrasting periods. In the first, 1972-80, referred to here as 'The Socialist Era', the Jamaican government pursued goals of self-reliance combined with seeking to integrate tourism into Jamaican life. In the second period, 1980-89, 'The Period of Capitalism', emphasis was shifted to reducing government intervention and pursuing foreign exchange earnings. A comparison of tourism development during these two periods reveals that during the 'Socialist Era' some success was achieved in the Jamaicanisation of tourism but at the same time government policies contributed to an overall decline in the industry as measured by the traditional indicators of tourist arrivals, hotel occupancy, hotel provision and employment. During the 'Period of Capitalism' a change in policy is associated with a successful recovery of tourism numbers but an increasing tension between locals and tourists. The study cannot provide causal explanations of the links between policy shifts and tourism development. The wide range of external variables, including oil crises and world inflation, that occurred during the periods is too great to admit this kind of certainty. However, the policy background provides an important context for understanding the link between policy and development in one of the oldest and most well-developed tourist destinations in the Caribbean.

\section{Introduction}

This paper presents the findings of a study designed to examine the role of public policy in the development of tourism with specific reference to the Caribbean island of Jamaica. The full study explored the period from 1970 to 2000 . This paper focuses on the two periods 1972 to 1980 and 1980 to 1989 . In policy terms, these represent two very distinct and different periods. In the first, 'The Socialist Era', the goals of pursuing 'self-reliance' were combined with integrating tourism into Jamaican life. In the second, 'The Period of Capitalism', emphasis was shifted to reducing government intervention and pursuing 'structural adjustment' policies. Against these different policy backgrounds, the paper explores and explains how tourism public policy developed in Jamaica and how this affected tourism development at a macro level. Jamaica represents an interesting study as it has one of the oldest and most well-developed tourism industries in the Caribbean.

The study was not intended to be prescriptive. Rather, with regard to public policy and tourism development, it sought to analyse what happened, how it happened, why it happened, and who was responsible. Specifically, some questions that the study sought to address included: 
- how has public policy, and specifically tourism public policy, been determined in Jamaica?; and

- how has public policy affected tourism development generally?

The importance of understanding the link between politics and tourism is especially significant for developing countries such as those in the Caribbean region. This is because many of these countries depend almost entirely on tourism for economic survival and governments have consequently played a key role in the industry. As suggested by Kosters (1984: 610): 'If a multi-disciplinary tourism science develops without the necessary ingredient of political analysis, it will remain imperfect and incomplete'. Important in this context also is the notion that even the formal choice of tourism as a development option often results from a decision made at the political level. As noted by Hall (1994), the results of research into the political aspects of tourism will help to facilitate and improve tourism planning through an increased understanding of public policy decision-making processes and also help maintain the long-term viability of the destination.

For each of the above two periods (1972-1980, 1980-1989), the discussion provides the political and policy background, outlines the main strands of government action in relation to tourism, examines the performance of tourism, by using some macro level indicators, and explores the links between government policy and action on the one hand and tourism performance on the other. It then uses this information to contrast the experience of the two periods and draws conclusions about the relationships between government policy and tourism development.

Clearly, a study like this cannot provide precise causal explanations of the links between policy shifts and tourism development. This is one consequence of taking a macro level focus to tourism policy-making and development. At this level, the indicators are clearly influenced by so many external factors including, for example, oil crises and devaluations. Time lags of uncertain length between cause and effect also present difficulties with interpretation and the length of time since the events further obscure some of the relationships. However, notwithstanding these difficulties, the information provided by the study does point to some highly interesting apparent relationships between policy on the one hand and development on the other. These provide the basis for attempts to interpret what happened in Jamaica in two very different time periods.

\section{Methodological Considerations}

The purpose of the study was to examine the role of public policy in the development of tourism with specific reference to Jamaica. A descriptive approach was adopted. Such an approach was explained by Mitchell (1989 in Hall and Jenkins 1995: 9) as the 'way in which the policy process actually occurs'. Independent and dependent variables were broadly identified as being public policy and tourism development respectively. The study then sought to determine whether any associations between the two could be discerned. In methodological terms, therefore, the study was correlational.

While recognising public policy as the independent variable, relative to the dependent variable of tourism development, the analysis was made more complex because there were a number of factors which themselves influenced 


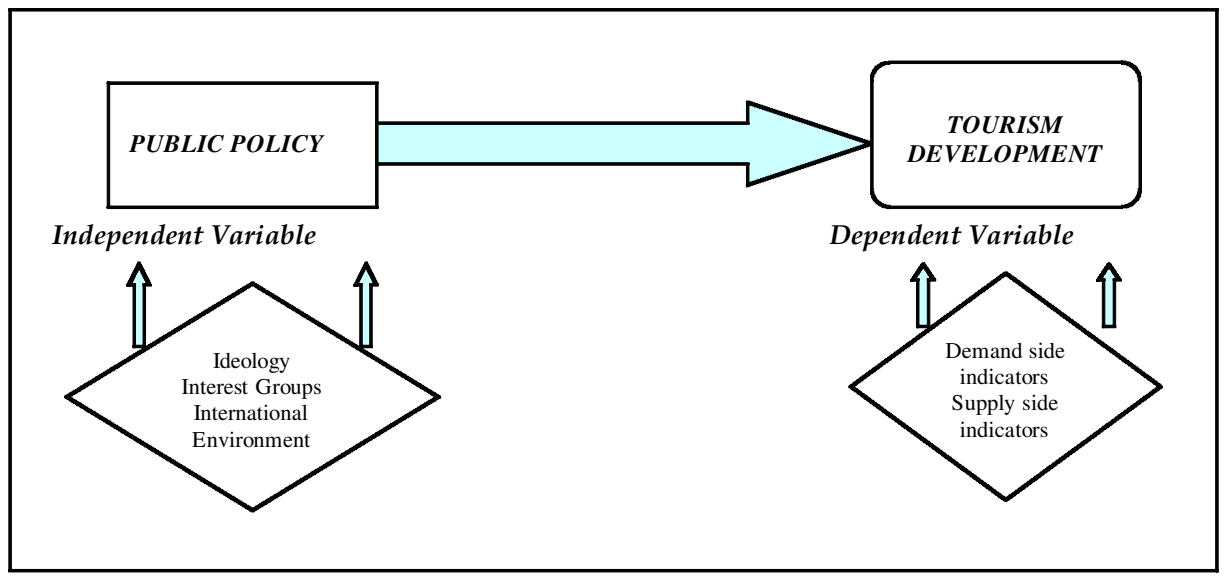

Figure 1 Relationship between independent and dependent variables

public policy. In the Jamaican context, factors such as ideology and the nature of the international economic and political environment have played a role in the determination of public policy during the periods under study.

Having identified tourism development as the dependent variable, the concern was with its quantification and measurement. A list of macro indicators that could be seen to constitute tourism development was identified. These were grouped into quantitative and qualitative factors from both the demand side and the supply side of the tourism industry. From the demand side primary concern was with issues such as visitor numbers and visitor expenditures. From the supply side interest lay in a host of factors including tourist facilities, infrastructure, host attitudes, environment and employment. Figure 1 illustrates the relationships between independent and dependent variables.

The methodology represented an eclectic mix of both primary and secondary data collection techniques, involving both quantitative and qualitative material. The most popular method of data collection, survey research, was not utilised due to the historical nature of the analysis. To the extent that opinions were sought, these were only used to supplement the information garnered from secondary data sources. Therefore, some primary data was collected from limited in-depth, elite interviews.

A rich source of data and information was found in existing documents, primarily those emanating from government ministries and departments. These documents provided both qualitative and quantitative information on the tourism industry. Within these, particular reliance for statistics has been placed on those produced by the Jamaica Tourist Board (JTB), which is the island's National Tourism Organisation (NTO). The JTB is a statutory body and clearly its data are collected for particular purposes for the marketing and development of tourism. Within these constraints, however, it does provide the only comprehensive statistical profile of Jamaica's tourism industry including important details on visitor arrivals, accommodation and expenditure. A list of JTB and other key sources are given in the list of references and in the Appendix. Secondary data were also obtained from academic books, journal articles and newspapers. 
The latter were used for historical information about the government's public policies and tourism development. They also proved useful for establishing the climate that existed in the tourism industry and the wider economy during the periods under analysis. A simplified content analysis of newspaper articles, from the oldest and the leading daily newspaper in Jamaica (Daily Gleaner), during the periods under study, were conducted. It needs to be noted that the content analysis of newspaper articles was not used to provide a quantitative count of the issues raised. Rather, it was used to provide further sources of information about the development of policy and links with the development of tourism. That is, the concern was more with the nature of the issues dealt with than with traditional indices such as word counts and frequency of topics.

Sampling had to be utilised as it would have been virtually impossible (and indeed, unnecessary), given the limited time available, to examine every issue of the newspaper. The criteria for selection of articles was based on the keywords of 'tourism' and 'tourist' and this yielded a list in excess of 5000 articles. An examination of 500 articles was felt to be appropriate and manageable for this study and so a systematic selection (with a random start) of every tenth article on the list was carried out. Once these articles were selected they were simply coded according to which were opinion pieces (including editorials) and which were simply news items.

\section{Discussion}

\section{An overview of Jamaica}

Jamaica, with an area of 28,389.2 square kilometres (4411 square miles) and a population of approximately 2.5 million, is the largest English-speaking island in the Caribbean. Since political independence from Britain in 1962, two political parties, the Peoples National Party (PNP) and the Jamaica Labour Party (JLP) have alternately held the reins of political power. Indeed, the Constitution of Jamaica recognises only one opposition party and this, in part, has mitigated against the successful development of 'Third Parties'.

The two party system in Jamaica is more than a political phenomenon; it is ingrained in the post-independence Jamaican culture and psyche. Elections in Jamaica have been characterised by violence and electoral fraud. Indeed, politics in Jamaica has often been described as 'a fight for scarce benefits and political spoils carried out by hostile tribes (the PNP and the JLP) perpetually at war'. The following discussion will explore how the politics of the 1970s and the 1980s, expressed through public policies, impacted on the development of the tourism industry.

\section{The socialist era: $1972-80$}

In 1972 the government of the PNP, led by Michael Manley, came to power in a landslide victory at the national polls. Faced with a high level of unemployment and a huge balance of payments deficit, it seemed opportune that the party's election slogan promised that 'Better Must Come. It's Time for a Change'. Indeed, according to Sharpley (1981:1) 'when the PNP government took office in February 1972 ... Jamaica was already facing its first serious balance of payments deficit since independence, and rising domestic inflation'. The new government 
embraced democratic socialism as a political ideology and indicated that it intended to put the people of Jamaica at the centre of all its new policies and programmes.

Tourism, an industry that revolves around people, was seen as an engine of growth for the 'new' society that the socialist regime sought to build. More importantly, the tourism industry at that time was assuming increasing importance to the island's economy, ranking second to bauxite in terms of foreign currency earnings. Therefore, the government, as part of a considered strategy aimed at energising the flagging economy, sought to devise policies and programmes for the development of the tourism industry.

Indeed, the then Minister of Industry and Tourism, P.J. Patterson, implored the country 'to accept as an undisputed fact of life, that ... the tourist industry has a key role to play in revitalising our economy and stimulating the possibilities of development' (Daily Gleaner, 17 August 1972). The government claimed to see no conflict between democratic socialism and tourism development. However, while the government sought to increase the flow of visitors to the island, its increasingly socialist rhetoric was partly responsible for the near collapse of the industry it had pledged to uphold.

The first issue that the new administration had to address was the bridging of the gap between the Jamaican hosts and their guests. It is posited that one reason for this gap was the island's historic legacy of Black servitude leading to feelings ranging from hostility to indifference toward Whites. This was exacerbated by the practice of barring locals from tourist hotels and beaches which, at that time, were the almost exclusive domain of wealthy, white tourists (Taylor, 1993). In fact, the colonial government, as part of a policy for the management of the beaches, had established a system of exclusive licences (through the Beach Control Act of 1956) which effectively resulted in Jamaicans being excluded from some of the finest beaches in the country. According to Taylor (1993:180): 'In this climate of exclusion there had naturally been little fondness for tourism among the ordinary people. Indeed, maintaining the industry in an atmosphere of isolation from the masses of the population had built up a store of resentment against it.'

The new administration acknowledged this state of affairs when the Tourism Minister declared that 'one of the factors in our attitudes toward visitors which has pushed our industry to the point of collapse is the growing tendency in our society - as so within the industry - to view everything exclusively in racial terms' (Daily Gleaner, 17 August 1972). For the government of the PNP, therefore, further tourism development in the island depended on the formulation and implementation of an inclusionary policy that would effectively bridge the gap between hosts and guests.

At a time when the government was trying to come to terms with the negative attitudes of the local population toward visitors, adverse international economic and political conditions were to have a further deleterious effect on the tourism industry. In 1973, war again erupted between Israel and the Arab world and this precipitated an energy crisis, which was unprecedented on the international scene. The energy crisis dealt a serious blow to the international travel trade and resulted in spiralling inflation globally, which affected Jamaica's key markets of 
the United States and Canada, which in 1972 accounted for $87 \%$ of visitor arrivals (Taylor, 1993: 183).

The question is, how did the government, through public policy, respond to these crises? In 1975 the Minister of Industry, Tourism and Foreign Trade presented a document to the House of Representatives, which was deemed a new charter for tourism. The document was titled Growth Through Integration and contained government's policies and strategies for the development of the tourism industry. This document (later refined into a Ministry Paper, No. 61, 16 December 1975) represented the first coherent attempt by any Jamaican government to prepare a comprehensive policy for the development of tourism. Prior to this, tourism development had proceeded in an ad hoc and uncoordinated manner. The only indications of the tourism policies of successive governments, up to this point, were contained in three major pieces of legislation, one of which had been passed during the colonial era.

The first was the Tourist Board Act of 1955, which established the Jamaica Tourist Board as a statutory body responsible for destination promotion and product development. The second was the Hotels (Incentives) Act of 1968, which sought to stimulate investment in hotel accommodation by granting tax incentives and duty concessions. The third and final piece of legislation, which dealt specifically with the tourism industry, was the Resort Cottages (Incentives) Act passed in 1971, but with provisions that were made retroactive to 1968. This latter Act was similar to the Hotels (Incentives) Act, but dealt with cottage style accommodation facilities.

The government claimed that through the policies and strategies contained in the new document 'the previous segregated image of the industry from the rest of the Jamaican society, from the rest of the economy, and from the social aspirations of the people' would be changed (Ministry Paper, No. 61, 16 December 1975). The document was the result of widespread consultations with concerned interests in the public and private sectors of the tourism industry. From this consultative process the government was able to define two broad policy goals for tourism development as being:

- the maximisation of economic benefits; and

- the integration of tourism into Jamaican life.

These broad policy goals were sub-divided into five specific objectives, namely:

(1) maximising foreign exchange earnings;

(2) increasing employment;

(3) increasing domestic tourism;

(4) worker participation and development;

(5) promotion of indigenous values in the cultural ambience of resort areas.

Clearly, a great deal of the government's policy direction as it related to tourism development focused on what was termed the 'Jamaicanisation' of the tourism industry. This concept was multifaceted. Not only did it concern the increased involvement of Jamaicans in hotels and other tourism facilities with regard to ownership and employment, but it also meant an increase in domestic tourism. Some felt that it was this policy of 'Jamaicanisation' which prevented the collapse of the tourism industry during the turbulent years of the Manley regime. 


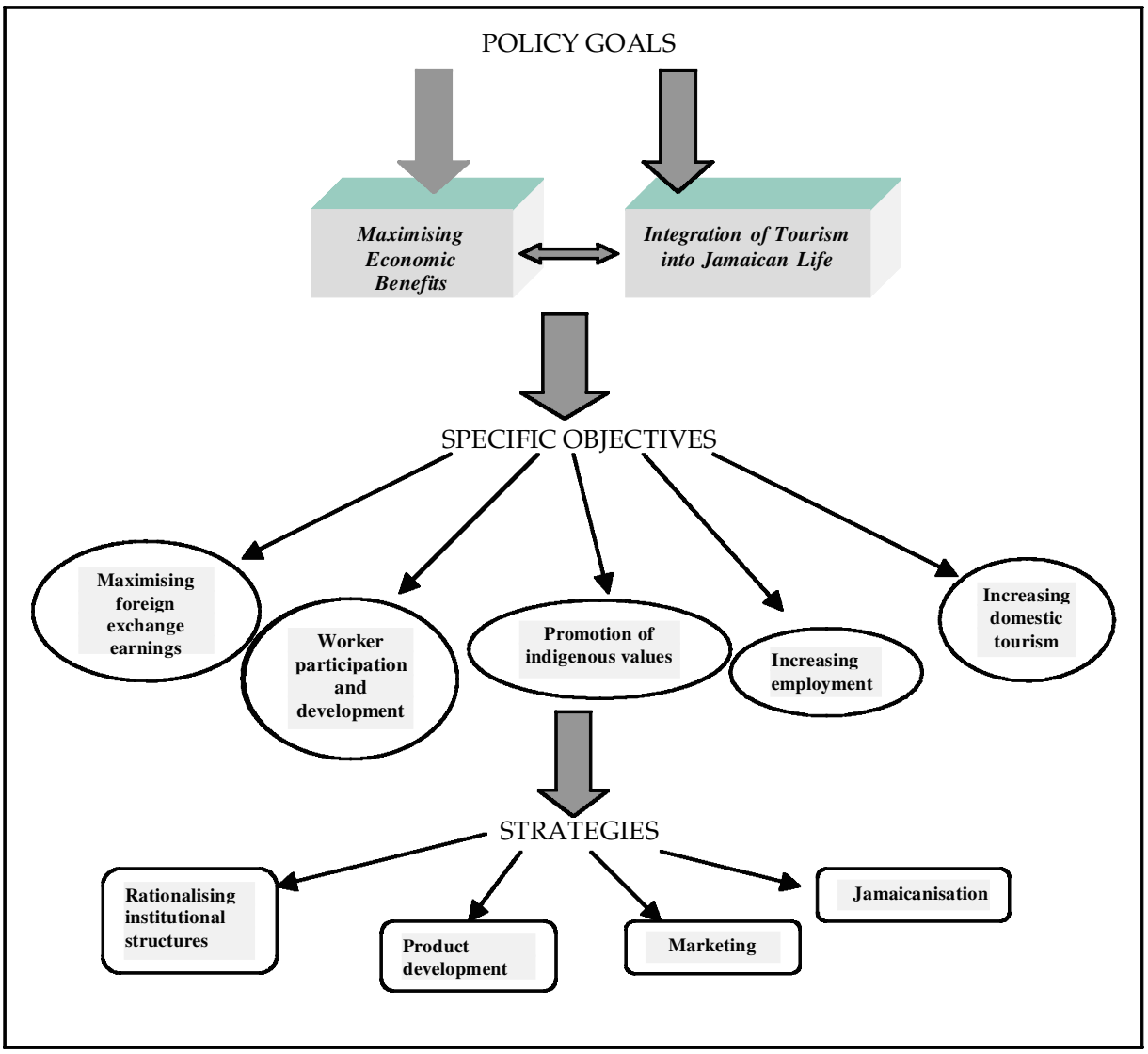

Figure 2 Policies and strategies for tourism development (1975)

The policy goals are set out diagrammatically in Figure 2. Those concerned with 'Jamaicanisation' balance those related to economic benefits with both being interdependent. These, in turn, are translated into specific objectives, with 'worker participation,' 'promoting indigenous values' and 'increasing domestic tourism' reflecting the 'Jamaicanisation' goal; and 'maximising foreign exchange earnings' and 'increasing employment' reflecting the economic goals. Interestingly, as shown in Figure 3, in institutional terms, tourism remains with the Ministry of Industry, Tourism and Foreign Trade with its 'economic' orientation.

While the government's new charter for tourism development represented the first attempt by a Jamaican government to articulate a comprehensive policy aimed at directing the development of the tourism industry, it, unfortunately, also illustrated the government's own ambivalence towards the industry. That is, while on the one hand the government emphasised the importance of the industry, on the other hand, its policy of 'Jamaicanisation' gave the impression that it did not openly welcome foreigners and foreign investment. In addition, its foreign policy of developing increasingly close ties with Cuba and the rest of the socialist world served to alienate its most important and closest western neigh- 


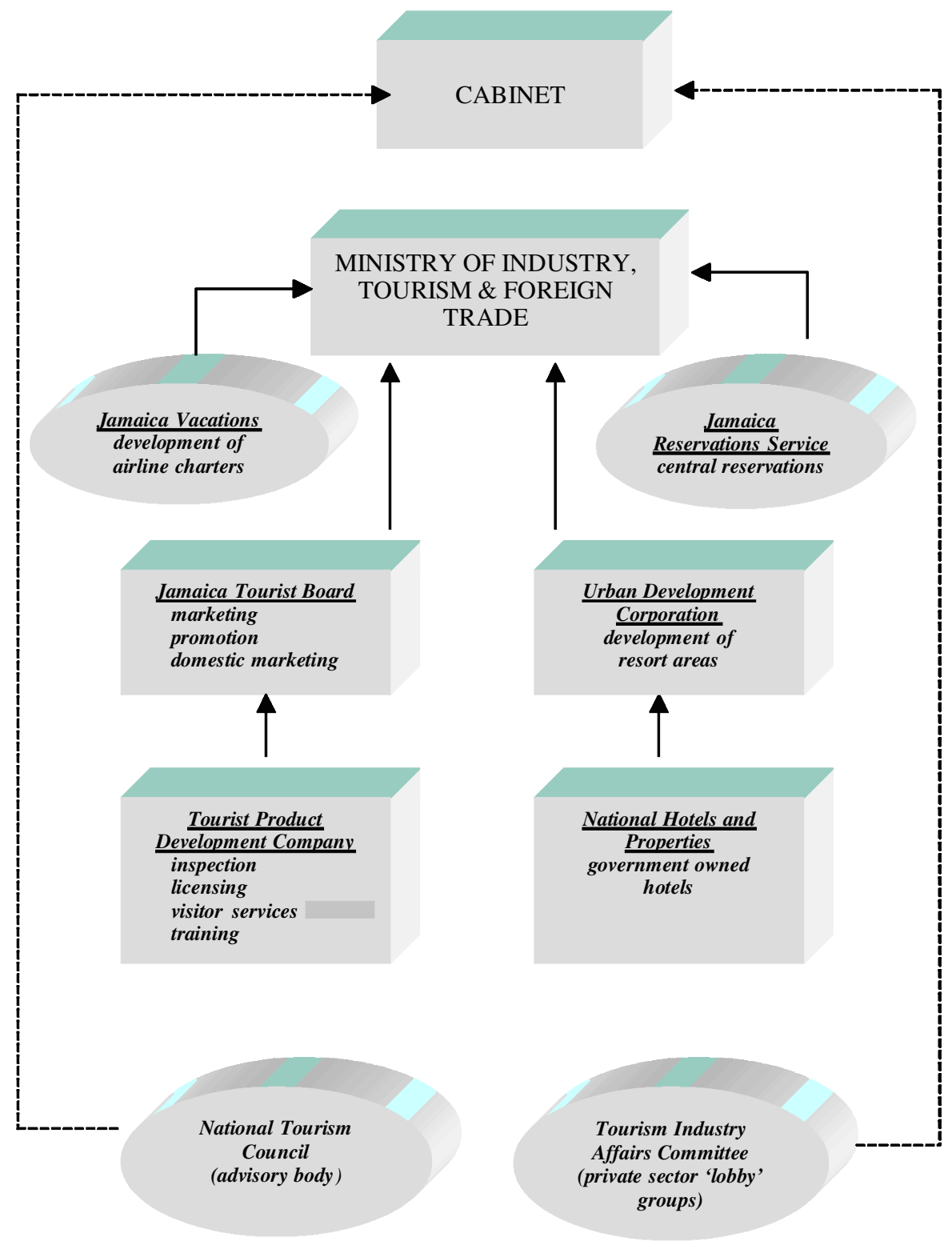

Figure 3 Tourism institutional structures (1975)

bour, the United States, which provided the source market for the vast majority of the island's visitors.

The idea that the Jamaican government's socialist posture and rhetoric was one of the main factors leading to the decline in the tourism industry was often cited in the Daily Gleaner during 1975 and 1976. A letter to the Editor on 18 November 1975, read, in part, as follows: 'Many observers think that the propa- 
gation of the tenets of socialism is one of the chief causes of our deteriorating tourist trade and they advance many arguments to substantiate this....' In 1976a government back-bencher cited the government's 'ideological posture' and 'current attitudes of anti-Americanism even at official level' as obstacles to the development of tourism in Jamaica (Daily Gleaner 24 March 1976).

Accompanying the government's political ideology of socialism was the influence of the economic theory of dependency to which many in the PNP regime subscribed to at the time. 'Between 1972-1980 the Prime Minister of Jamaica was one of the leading politicians in the Third World who had made the dependency theory his ideology' (Blomstrom \& Hettne, 1984: 114). Dependency theorists stressed 'self reliance' and criticised the dependence on tourism as a source of income, 'a practice which, in their opinion, merely emphasised Jamaica's role as an object of exploitation and intensified its already extreme cultural dependence' (Blomstrom \& Hettne, 1984: 114). Clearly, a paradoxical situation had been created between the government's promotion of tourism as a sort of panacea for the country's economic ills and its political and economic philosophies, which saw tourism as a vehicle of socio-cultural and economic dependency.

To exacerbate an already perplexing situation, high levels of crime and violence accompanied the 1976 General Elections in Jamaica as both major parties (the PNP and JLP) fought for political power and territorial control. The government, seemingly unable to control the almost anarchical situation into which the country had been plunged, declared a State of Emergency in June 1976. The incidents of violence and the government's 'crackdown' were widely reported in the overseas press in which the island was depicted as an unstable, crime-ridden destination. This necessarily impacted negatively on the tourism industry.

The unstable internal political climate and the government's policy of 'Jamaicanisation' (which seemed, effectively, to be a reflection of the socialist policy of nationalisation of industry), contributed to a massive flight of capital from the country. Many hotels were closed down and the government was forced to assume ownership of these and other hotels that could no longer pay their mortgage bills due to low occupancy levels. By 1980 the government (through National Hotels and Properties, a subsidiary of the Urban Development Corporation) owned 17 of the largest hotels and so controlled about $60 \%$ of the first class hotel rooms on the island (Sealey, 1982: 41).

The government, however, remained intransigent and never openly acknowledged that its ambivalence was partly responsible for the downturn in the island's tourism industry, and, by extension, the entire economy. Rather, they declared themselves the victims of destabilisation policies of the CIA and the opposition JLP. Indeed, from as early as 1972, when the PNP took office, it assumed a defensive stance. In December 1972, the Minister responsible for tourism, in an address to the House of Representatives, disclosed 'another plot, this time to affect the tourism industry.... He said the government knew there were some people who were against the tourist industry and indeed was aware of plots to create disturbances in tourist areas. One of the latest aspects of these plots was a planned approach by a boat of men in khaki uniform with leaflets saying, 'Castro is about to land' ' (Daily Gleaner, 6 December 1972).

Undoubtedly, the economic and political problems in which the government 


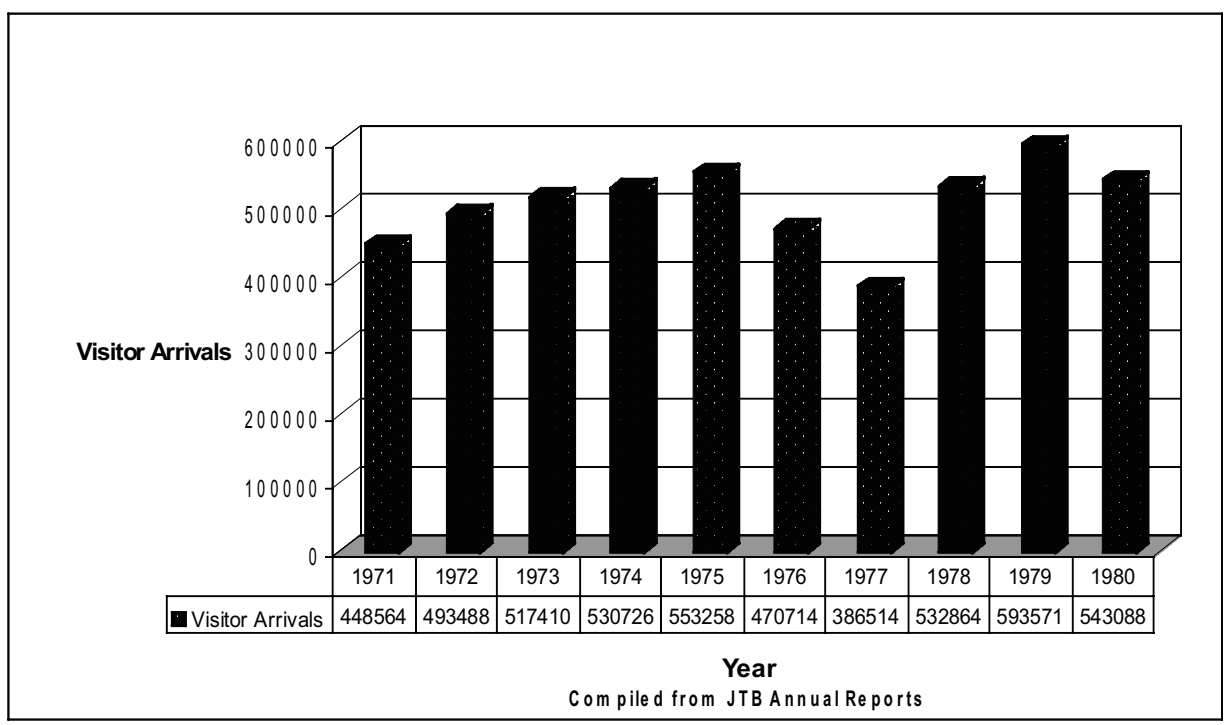

Figure 4 Visitor arrivals 1971-1980

found itself could be attributed to a combination of all the above mentioned factors. Blomstrom and Hettne (1984: 115) put it succinctly as follows:

Jamaica was thus gradually pushed into a severe economic, social and political crisis by a combination of the inherent adjustment problems of a new development strategy, the destabilising policies to which foreign capital interests always tend to resort when a dependent country embarks upon a new, 'hostile' political course, and the JLP's merciless campaign, which was facilitated by the traditional fear of communism. It is quite probable that the exaggerated confidence placed in the strategy of self-reliance helped prepare the ground for the economic failure which eventually forced the Manley government into a politically unviable situation.

It was, therefore, no surprise that during the Manley regime of the 1970s, allowing for time lags, all the measurable macro indices of tourism development (notably visitor arrivals, visitor expenditure, growth in accommodation facilities, and employment) recorded erratic development with some significant declines. In addition, expenditure by the government on tourism marketing and promotion seemed to reflect the politico-economic exigencies of the period.

In Figure 4 visitor arrivals to the island between 1971 and 1980 are illustrated. It will be noticed that between 1975 and 1977 visitor arrivals declined significantly from 553,258 to 386,514 , a drop of almost $30 \%$. This period marked the government's announcement of its new policies for tourism development, which were expected to foster growth in the industry. However, just the opposite happened, in part at least, due to the very ambivalence of these policies along with the overall political and economic philosophies of the government. In addition, the political violence that marred the 1976 General Elections and the subsequent State of Emergency (which was not lifted until early 1977) are likely to have further contributed 


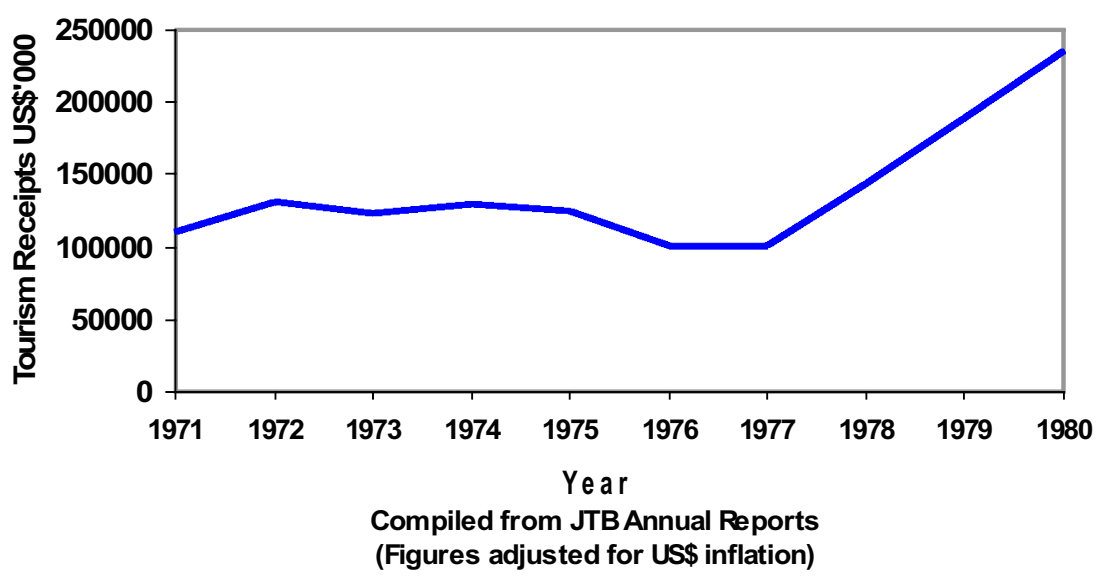

Figure 5 Tourism receipts 1971-1980

to the decline in arrivals. With the lifting of the State of Emergency and a return to relative calm, visitor arrivals increased in 1978 and 1979. However, this was followed by another drop in arrivals in 1980, which, in part, can be directly attributed to the violence which again accompanied General Elections in that year.

Figure 5 shows international tourism receipts during the period. These remained relatively stable between 1971 and 1975 after which they declined, reaching their lowest levels in 1977, in keeping with the turbulent internal political situation. However, the receipts from visitors showed marked increases after 1977 despite the aforementioned decline in visitor arrivals between 1979 and 1980. Indeed, in the election year of 1980, tourism receipts reached their highest level in almost a decade. A plausible explanation for this apparent anomaly is the strong influence of inflationary trends in the world, and particularly in the North American market. However, adjusted for US dollar inflation, the figures show exactly the same pattern, although with US inflation reaching over 10\% in 1979 and 1980 the real growth is less pronounced than that suggested in money terms.

Figure 6 shows the occupancy levels of the accommodation facilities (i.e. total rooms in hotels, villas, apartments and guest houses) on the island during 1972 to 1980 . Over the period they averaged approximately $42 \%$. There are many factors that influenced this, including the lack of buoyancy in international arrivals. It is possible that this average might have been even lower were it not for the success of the Domestic Marketing programme of the JTB which encouraged Jamaicans to holiday at home in keeping with government policy of 'Jamaicanisation' of the industry. Indeed, according to Taylor (1993: 184): 'The emergence of a substantial domestic market for holiday facilities was a highlight of the Manley era (19721980). This development was encouraged by his government's Domestic Holiday Program, its tight foreign exchange restrictions on travel abroad by Jamaicans and the Discover Jamaica promotional campaign by the Tourist Board to 


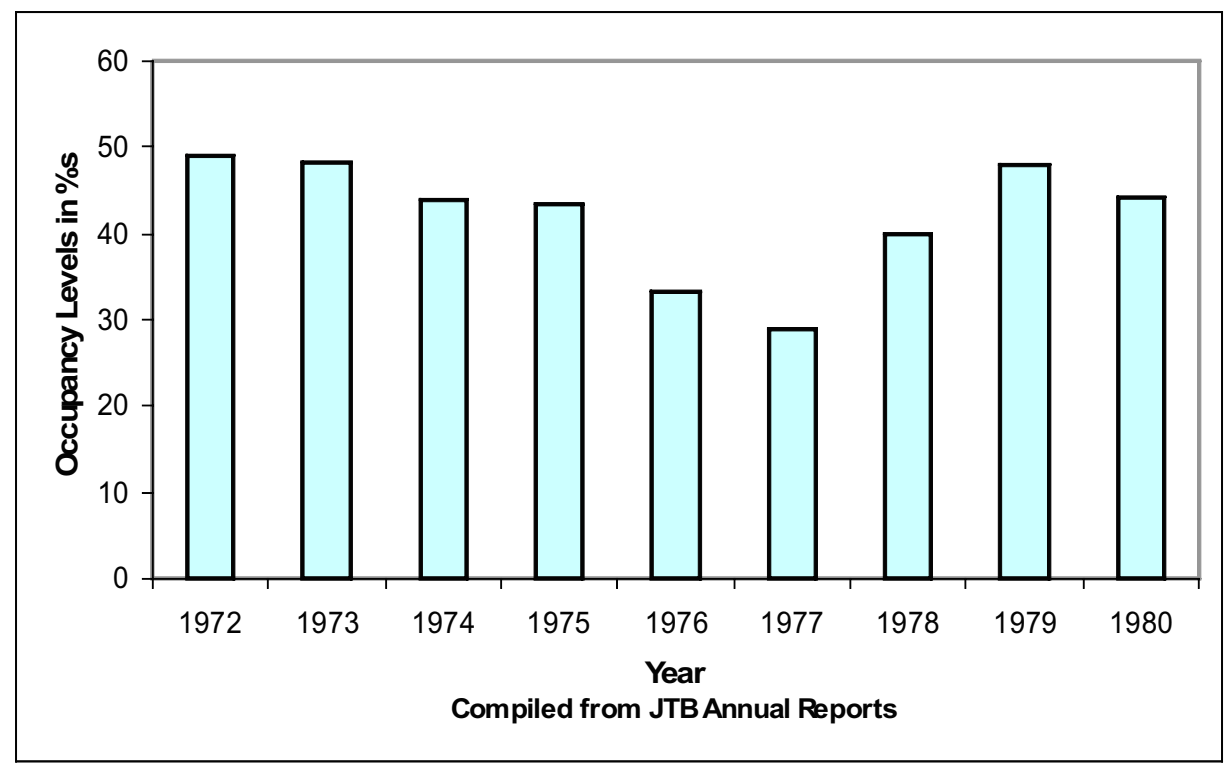

Figure 6 Occupancy levels in accommodation facilities 1972-1980

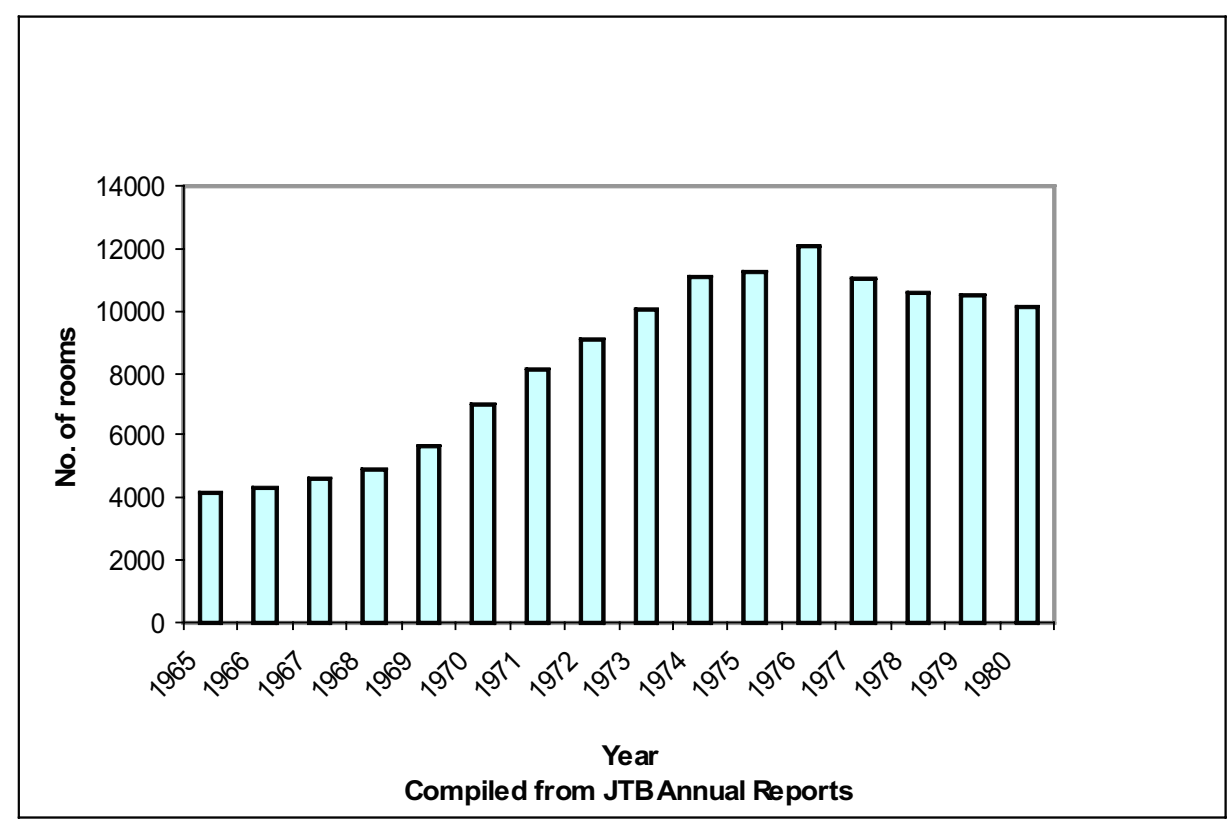

Figure 7 Accommodation facilities 1965-1980

entice locals to spend their vacations in the island.' The decline in occupancy levels between 1975 and 1977 and again between 1979 and 1980 is in keeping with the decline in international visitor arrivals during the same periods, the latter coinciding with the general election. 


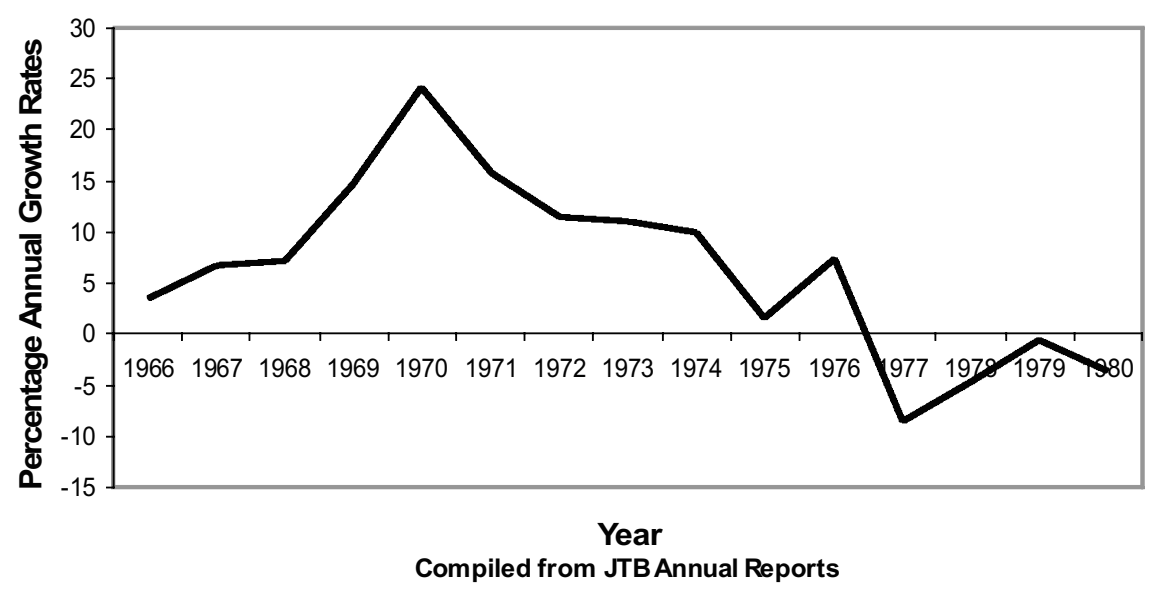

Figure 8 Percentage annual growth in accommodation facilities 1966-1980

Another important indicator of tourism development is the quantity of accommodation facilities and the growth of these over time. Figure 7 illustrates the number of accommodation facilities in the island between 1965 and 1980 while Figure 8 illustrates the percentage annual growth rate of accommodation facilities during the same period.

As mentioned previously, the introduction by the government in 1968 of incentives for investment in accommodation facilities was expected to have impacted significantly on the number and growth of hotel and villa type rooms in the island. The statistics demonstrate that in 1966, 1967 and 1968 the rate of growth of accommodation facilities was 3.5\%, $6.8 \%$ and $7.2 \%$ respectively. However, in 1969, the rate of growth more than doubled to $14.7 \%$ and in 1970 growth was $24.7 \%$. From 1971 up until 1974, the annual rate of growth of accommodation facilities ranged between $9.9 \%$ and $15.7 \%$. Growth rates, post 1968, therefore give some credence to the notion that the provision of incentives by the government had a positive impact on the growth and quantity of accommodation. Rates of growth slowed between 1974 and 1975 and between 1975 and 1976, although the number or rooms continued to increase. Between 1976 and 1980 there was negative grow th in accommodation facilities and the number of rooms also declined. It should follow that a logical explanation for the slowing of growth in accommodation facilities and the decline experienced after 1976 would be that this resulted from the suspension of incentives by the government as announced in its tourism policy document of 1975. It will be recalled that in the latter part of the 1970s the government had assumed ownership of a number of hotels facing financial difficulties. It could not therefore be expected to impose a second cost to taxpayers (and indeed decrease its own revenues) by providing incentives for hotel development in competition with its own property holdings.

Notwithstanding the rationale for the suspension of incentives, it is no doubt possible that this policy might have contributed to the decline in accommodation 


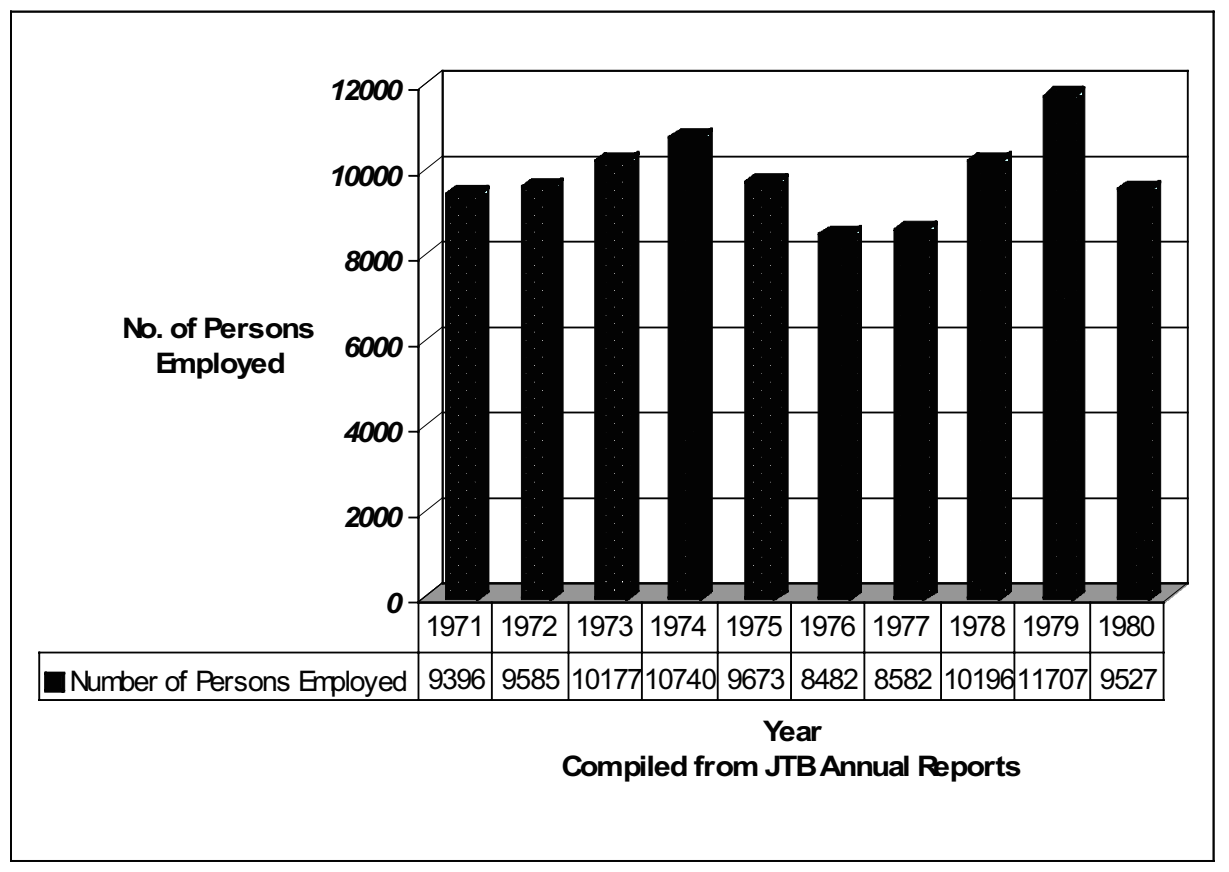

Figure 9 Number of persons employed in the accommodation sub-sector 1971-1980

facilities and growth rates. However, it is more likely that this phenomenon resulted from the flight of capital from the island and the lack of investor confidence due to the government's policy of 'Jamaicanisation'. Indeed, Henry (1986: 4) noted that 'Jamaica was regarded as a bad risk for foreign investors during the 1970s'.

One of the major goals of any government with regard to tourism development is to increase employment. Indeed, it will be recalled that one of the specific objectives articulated by the government in its 1975 tourism policy was to increase employment. According to Michael Manley (1974:101), tourism 'is one of the most labour intensive industries left to the modern world'. On the face of it, the statistics suggest that the government did not perform creditably in this area as the number of persons employed directly in the tourism industry showed a marginal decline between 1972 when the government assumed office and 1980 when they demitted office. However, it must be recognised that the statistics only reflect direct employment (specifically employment in the accommodation sub-sector) and so the indirect and induced employment figures are not known. In addition, the statistics do not indicate the level of skilled versus unskilled employment.

Hines (1974: 9), in referring to the tourism industry, suggested that the proportion of unskilled workers is much higher in this industry than in the economy as a whole. The proportions are $43 \%$ and $15 \%$ respectively'. Given that the accommodation sector represents the largest component of the tourism industry, the fact that employment did not increase significantly during the PNP regime might nevertheless be an indication of the failure of this aspect of the government's policy. Figure 9 shows the employment generated by tourism, in the accommodation sector between 1971 and 1980 . 


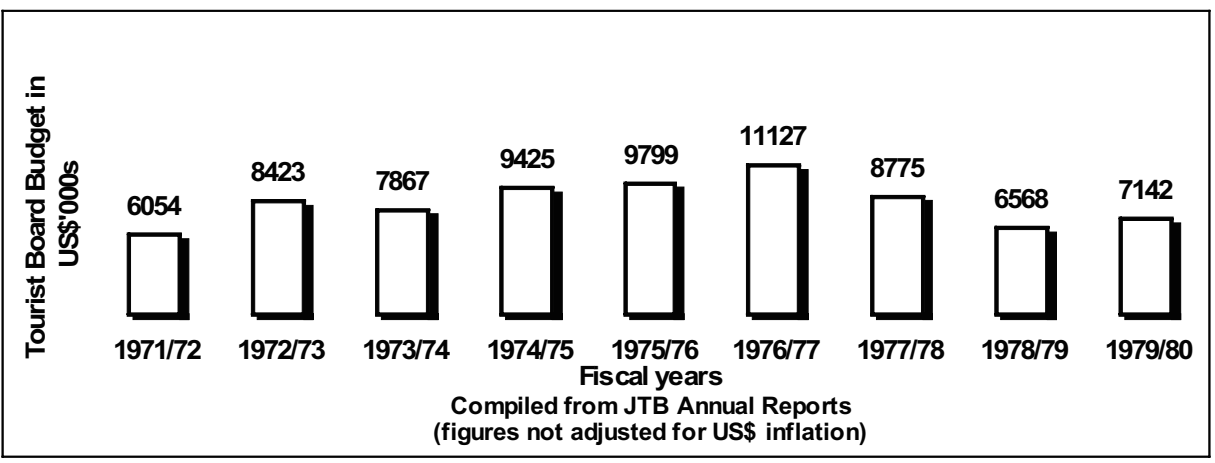

Figure 10 Jamaica Tourist Board budget 1971-1980

Figures are on a fiscal year basis from April 1 in one year to March 31 in the following year. In addition figures represent the amounts approved by the government which is not necessarily the same as the amount actually dispensed.

The final statistic, which will be examined in this section, is that of government spending on the Tourist Board (see Figure 10).

The government's contributions to the JTB can be seen to fluctuate, not in keeping with the stated policy of maximising returns from the industry, but rather in keeping with the political exigencies of the period. That is, when the government's term of office commenced in 1972, grants to the JTB increased by approximately $37 \%$, representing in the region of $3 \%$ of government expenditure (IMF, 1990). Once the government was somewhat settled in office (1973-74), this declined by approximately $7 \%$, accounting for the equivalent of about $2 \%$ of government expenditure. Thereafter grants increased steadily until, during the period of the State of Emergency (1976-77), grants to the JTB reached their highest levels in a decade. However, this figure needs to be set against other internal changes in government expenditure by this socialist government, which meant that in relative terms they declined as a proportion of government expenditure to about $1 \%$. In other words, although the government grants to the JTB increased, arguably to protect the image of the destination overseas in light of the negative publicity it was receiving, in reality the JTB received a smaller proportion of government expenditure. After this crisis, grants to the Tourist Board declined and only increased marginally in the election period of $1979-80$. By then, they represented $0.2 \%$ of government expenditure.

The preceding discussion has demonstrated the political and socio-economic turbulence that beset the island of Jamaica during the socialist era (1972-80). Given the pivotal role played by tourism in the national economy it was no surprise that the industry was affected by the instability which pervaded the entire society. It is difficult to isolate a single factor which caused this adverse situation, and it is evident that it resulted from the convergence of both internal and external phenomena. To the credit of the Manley regime, they did formulate a tourism policy which was intended to reflect the importance of the industry to the island's development. However, these tourism policies reflected the ambivalence of the government toward the tourism industry. This, along with the 
alleged destabilising activities of both the CIA and the JLP and the inability of the government to deal with rising crime and violence, particularly during the two national elections, undoubtedly dealt serious blows to the island's tourism industry. Externally, world-wide economic difficulties, especially inflationary pressures in important source countries, also contributed to the less than spectacular performance of the industry.

However, while public policies during the Manley regime did not succeed in maximising the potential of the industry, they did succeed in changing the image of the industry particularly for Jamaicans. According to Taylor (1993: 184), the Prime Minister later boasted that his government achieved success in that 'we set out to break the old elitist pattern in which tourist hotels were like enclaves, shut away from the local population by psychology as much as by price'. By the end of the regime, the government had a substantial holding in tourism facilities owing to the failure of economic policies, coupled with the flight of capital and the slowing of investment partly occasioned by the government's embrace of socialist doctrines. Sealey (1982: 41) stated that this latter development was 'quite unlike anywhere else in the Caribbean'.

By 1980 the JLP had succeeded in uprooting the PNP from office. This 'led to rather dramatic shifts in Jamaica's policies of development and foreign affairs' (Blomstrom \& Hettne, 1984:116). In the next section the fate of Jamaica's tourism industry under the capitalist regime of the JLP is discussed.

\section{The period of capitalism 1980-89}

The year 1980 ushered in the government of the JLP, led by Edward Seaga. By this time, the country was experiencing deep economic, social and political crises. The new government eschewed the ideology of socialism and its attendant economic philosophy of self-reliance, which, it felt, had brought the country literally to its knees. Indeed, 'Edward Seaga's first official act on taking office was to expel the Cuban ambassador and the first anniversary of the JLP government was celebrated by a diplomatic break with Cuba' (Blomstrom \& Hettne, 1984: 116).

Instead, the new government declared itself to be capitalist and expressed the view that Jamaica's economic development model would be akin to that being pursued by Puerto Rico which was, in essence, a satellite state of the United States. According to Seaga: 'The Puerto Rican model of economic development was more relevant to Caribbean lifestyles and objectives than that of Cuba - the Caribbean was near the world's richest continent - the United States - and that was its greatest asset - the Caribbean was ideal not for its bauxite, oil or tourism but as a base for re-exporting goods to the North American market' (Daily Gleaner, 9 December 1979, as quoted in Blomstrom \& Hettne, 1984: 115).

This development model, which can be termed 'dependent capitalism' was welcomed by the United States (then led by Ronald Reagan), which gave Jamaica special treatment in terms of economic and trading relations. In light of the importance of the United States' market to Jamaica's tourism industry, the foreign policy of the new government, which aimed at renewing friendly relations between the two countries, necessarily impacted positively on the development of the industry.

After the change of government in October 1980, the tourism portfolio was, for 
the first time in the nation's history, invested in a separate Ministry. The new Minister of Tourism was a former Director of Tourism and was given the mandate to carry out the government's policy for the tourism industry which was to 'maximise revenue earnings from the sector and to provide conditions which would facilitate growth' (JTB Annual Report, 1981/82). The fact that an entire Ministry was devoted to tourism concerns, is, ostensibly, an indication of the increased importance that the JLP attached to this economic sector. Importantly, consequent on the decline of the bauxite industry in 1982, tourism, for the first time, became the main foreign exchange earner for Jamaica (Hayle, 1997). However, unlike during the socialist years, there was no single document that outlined government's policy direction for the industry.

By 1984, the Minister of Tourism resigned and the tourism portfolio was once again incorporated into another Ministry, that of Mining and Energy. The reason for this is not entirely clear. It might have been that in the absence of an obvious replacement Minister the government used this move to solve a short-term difficulty and it endured. It was nevertheless apparent that the need for a comprehensive policy outlining future directions for the tourism industry was seen as important although this was not given priority status by the government. Indeed, up until 1987 (almost seven years into the JLP regime) discussions were still ongoing about the development of a tourism 'Master Plan'. As a result, during the 1980s the best indication of government's policy direction for the tourism industry was to be found in disparate budget speeches of the Prime Minister and in Annual Reports of the JTB.

In keeping with the tenets of capitalism, which supported less government intervention in the economy and more private sector involvement, the JLP almost immediately sought to divest itself of those hotel properties which had been taken over by the previous government through the Urban Development Corporation's subsidiary company, National Hotels and Properties. By 1982 only two hotels were still fully owned and operated by the government with the others having been leased to private sector interests (Sealey, 1982).

The leader of the JLP firmly believed that the management of the economy was the primary goal of his administration and indeed, one of the party's slogans stated that 'It Takes Cash To Care'. Hence, the government embarked on a path that was intended to ensure the full economic recovery of the island. In particular, the government sought the assistance of international lending agencies, most notably, the International Monetary Fund (IMF), to pull the country from the brink of economic ruin. While Jamaica's relationship with the IMF had commenced in the late 1970s, it was in the 1980s that this relationship grew and blossomed. In the early 1980s, no less than three IMF agreements were signed (1981,1984 and 1985) 'each of them specifying performance targets for the economy' (Curry, 1992: 201). The IMF agreements called for tighter control of the fiscal budget, restrictions on lending by the central bank and restrictions on commercial credit. In effect, the 1980s can be termed the period of 'structural adjustment' of the Jamaican economy. The external debt and associated devaluations of the currency, combined with the hardships brought by structural adjustment policies, helped to contribute to a view that the JLP were more concerned with economics and finance than with social well-being.

In 1986 the government suspended the Hotels (Incentives) Act and the Resort 
Cottages (Incentives) Act 'on the grounds that economic policy changes had benefited the hotel sector substantially and so they were no longer needed' (Curry, 1992: 205). Evidently, the government was satisfied that its economic policies were impacting positively on the development of the tourism industry and was convinced of the direct link between fiscal incentives and investment in the hotel sector.

The economic policies of the government seem to have led to a phenomenal increase in 'black market' activities. Given that the tourism industry had become a major earner of foreign exchange it was no surprise that these illegal activities became rampant in the resort areas. According to the JTB Annual Report of 1982/ 83 , 'high level discussions took place during the year to curb harassment of visitors by Jamaicans seeking to make illegal currency transactions'. The hardships occasioned by the government's structural adjustment policies also contributed to the escalation of visitor harassment. It was clear that a new element had been introduced into the attitudes of Jamaicans toward visitors. Not only were visitors often viewed with hostility and resentment, but were, more importantly, seen as 'cash cows' to be 'milked' at every opportunity. In fact, one author claimed that the 'further Jamaica moved away from colonialism the more the visitor became an object of perceived wealth' (Hayle, 1997: 19).

So serious was the problem of harassment that in the Budget Debate of 1985/ 86, delivered on 6 June 1985, the Prime Minister of Jamaica announced an amendment to the Tourist Board Act which was: 'designed to pull together all the main operators in tourism under a system of licensing where proper standards can be set and standards maintained. The issuing of licences will also be used as an effective means of preventing touts, pimps, hustlers and drug pushers from jeopardising the tourism industry'. In 1986/87, the Prime Minister declared that 'a recent survey of the tourism industry demonstrated that the molestation of visitors and lack of courtesy on the part of some Jamaicans were the main deterrents to the health of the tourism industry' (Budget Debate 1986/87). By 1987/88, it appeared that the government had still not been able successfully to address the 'harassment problem'. In the Budget Debate of that year the Prime Minister again expressed concern about this development in the tourism industry: 'If the elements of bad conduct and the hustling of drugs, craft items and other forms of visitor harassment are not brought to an end the indiscipline will discourage the growth of the industry and the benefits it provides to many'.

Ironically, at the same time that the government was grappling (somewhat unsuccessfully) with the problems of crime and harassment in the resort areas, it also boasted that the tourism industry had responded well to the structural adjustment programme. The indicators used to measure this success were cited as the growth in visitor numbers and the increase in tourism receipts. For the government, it appeared that the spread of harassment was unrelated to the way in which tourism was developing, particularly in terms of employment creation, redistributive benefits and social interactions between hosts and guests.

In January 1985 the entire economy was negatively affected by widespread demonstrations occasioned by an increase in gas prices. This event received adverse publicity in the overseas press. Moreover, reports of Jamaican gang activities in the key markets of North America and the UK further contributed to the negative press given to Jamaica overseas. 
Any discussion of tourism development during the 1980s must include some mention of the impact of all-inclusives. It will be recalled that early in the JLP regime, the government divested itself of several properties that had been acquired by the previous government during the turbulent years of the 1970s. Many of these hotels were bought or leased by Jamaicans and an important development that emerged was the all-inclusive concept. While the first all-inclusive hotel was opened by a locally owned and managed company, Superclubs, in 1978, the 1980s witnessed the mushrooming of the concept. The concept is explained thus: 'Based on the original Club Mediterranee formula, but greatly expanded, guests pay one price for their holiday - in advance and usually in the country of origin - for which all accommodation, food, drink, entertainment, sports facilities, tips, tours and airport transfers are included' (EIU, 1993: 40).

It is probable that the pervasiveness of the all-inclusives was in response to negative behaviour like harassment that was rampant in the resort areas at the time. Most guests in the all-inclusive complexes did not need to venture outside the confines of their hotels. Indeed, 'critics maintain that one important item not included [in the all-inclusive package] is Jamaica' (EIU, 1993: 40). This claim is however rejected by proponents of the concept who claim that all-inclusives contribute more to local economies than traditional European Plan (EP) hotels. It cannot be denied that all-inclusives consistently perform better than traditional EP hotels in terms of profits, occupancy levels and length of stay. In Jamaica in 1988 there were a total of 2780 all-inclusive rooms, or approximately $20 \%$ of the total rooms on the island. In the same year average occupancy levels at all-inclusives were $65.9 \%$ compared to $53 \%$ for EP properties (Caribbean Tourism Organization, 1994). Overall statistics on occupancy levels during the period under study were necessarily boosted by the performance of the all-inclusives. Critics further argue that the segregation of guests within the all-inclusive hotel enclaves creates increased resentment among locals.

All-inclusives, while they created increased profits for the hoteliers and boosted overall tourism statistics, might have exacerbated the problem of harassment. Nevertheless, all-inclusives undoubtedly made a significant contribution to the development of the tourism industry during the 1980s. According to Curry (199s) all-inclusives may have sustained tourism receipts when traditional EP hotels could not attract visitors to the island.

The discussion of the performance of the macro indices of tourism development during the period of capitalism is incorporated in the next section which compares the two periods.

\section{Comparison of the two periods}

A comparison of tourism statistics under the PNP regime of the 1970s and the JLP regime of the 1980s, demonstrates that in the latter period, most of the measurable macro indices of tourism development recorded noticeable improvement. For the purposes of comparison, 10 periods have been identified in each decade (1971-1980 and 1981-1990) between 1971 and 1990. Period one corresponds to 1971 and 1981, period two to 1972 and 1982, and so on, up to period ten (1980 and 1990).

In terms of visitor arrivals, Figure 11 demonstrates that during the regime of 


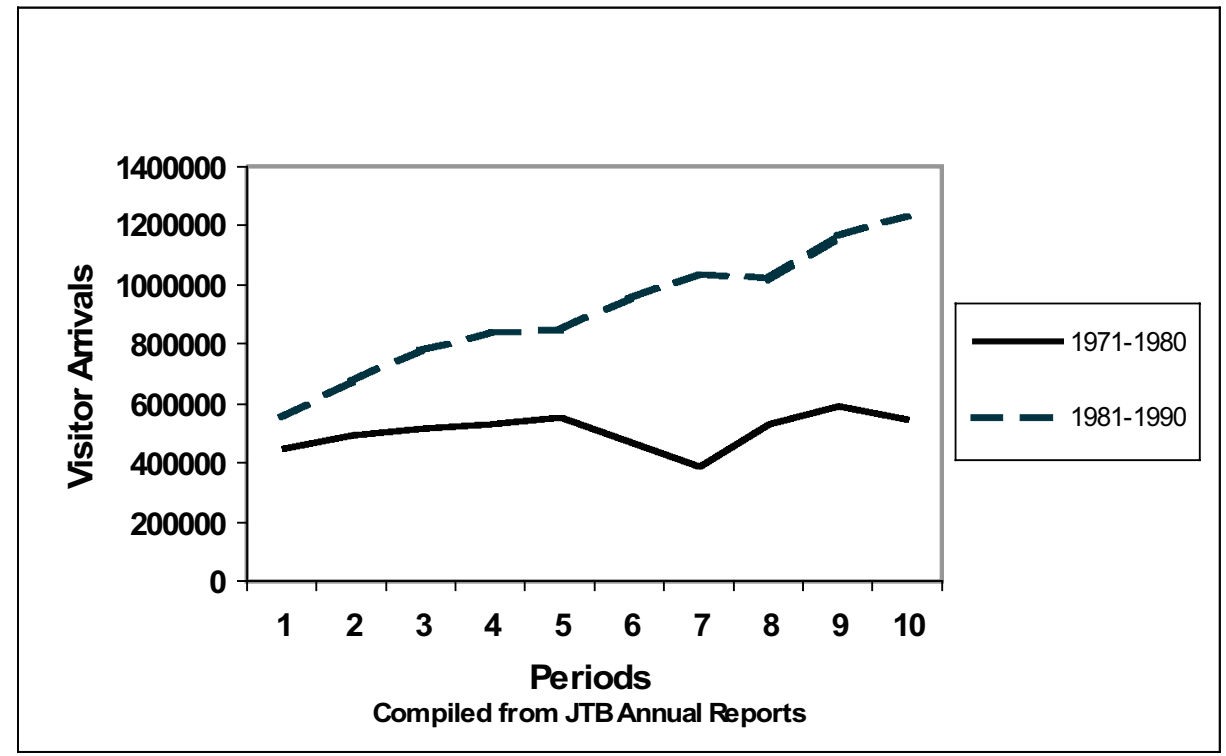

Figure 11 Comparative visitor arrivals 1971-1980 and 1981-1990

the JLP, visitor arrivals increased in every year except 1988. However, the government boast that 'the rebound of the tourism sector from the long slide of the 1970s to strong grow th in the 1980s is one of the earliest areas of demonstrable success in the programme of economic recovery' (Budget Debate, 1986/87) also needs to be set against the series of local currency devaluations and economic fluctuations in the source countries. The slight decline in arrivals in 1988 can be directly attributed to a factor extraneous to the policies of government, namely Hurricane Gilbert, which devastated the island in September 1988. While the decline in visitor arrivals during 1988 was only approximately $1.7 \%$, the decline in tourism receipts was much greater at $11.7 \%$ (see Figure 12). This is all the more remarkable given a US dollar inflation rate of about $4 \%$. One can surmise that the reasons for this might have been that hotels reduced room rates in an attempt to attract more visitors or that many of the attractions and other activities which account for the rest of visitor expenditure, were non-operational due to the hurricane. In addition, due recognition must be given to possible adverse economic conditions in the main target markets which would have impacted negatively on visitor spend. Nevertheless, in terms of both visitor arrivals and tourism receipts, the JLP can be seen to have performed better than the PNP government. Indeed, both statistics increased even during the election year of 1989, which was also accompanied by political violence.

The number of accommodation facilities also increased in every year during the JLP regime even after the suspension of hotel incentives in 1986. This was not the case under similar circumstances in the 1970s when incentives were also suspended. The notion that there is a direct causal relationship between investment in accommodation and fiscal incentives is therefore not supported. 


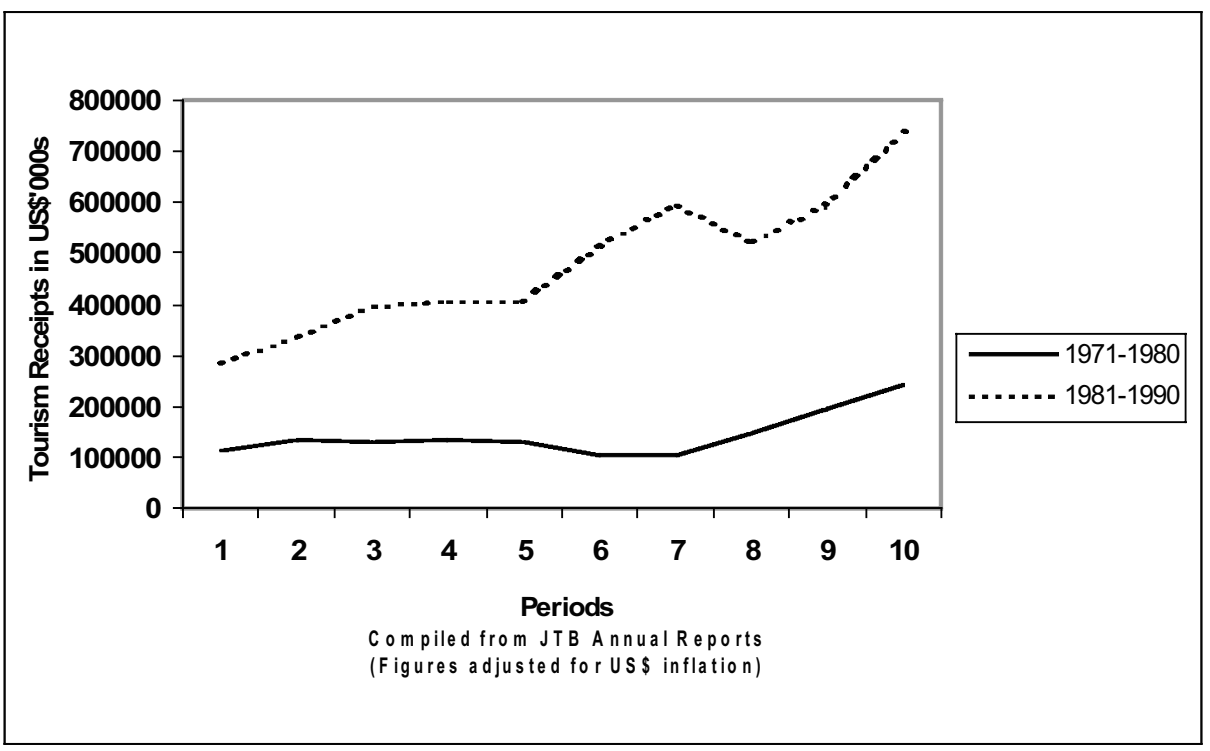

Figure 12 Comparative tourism receipts 1971-1980 and 1981-1990

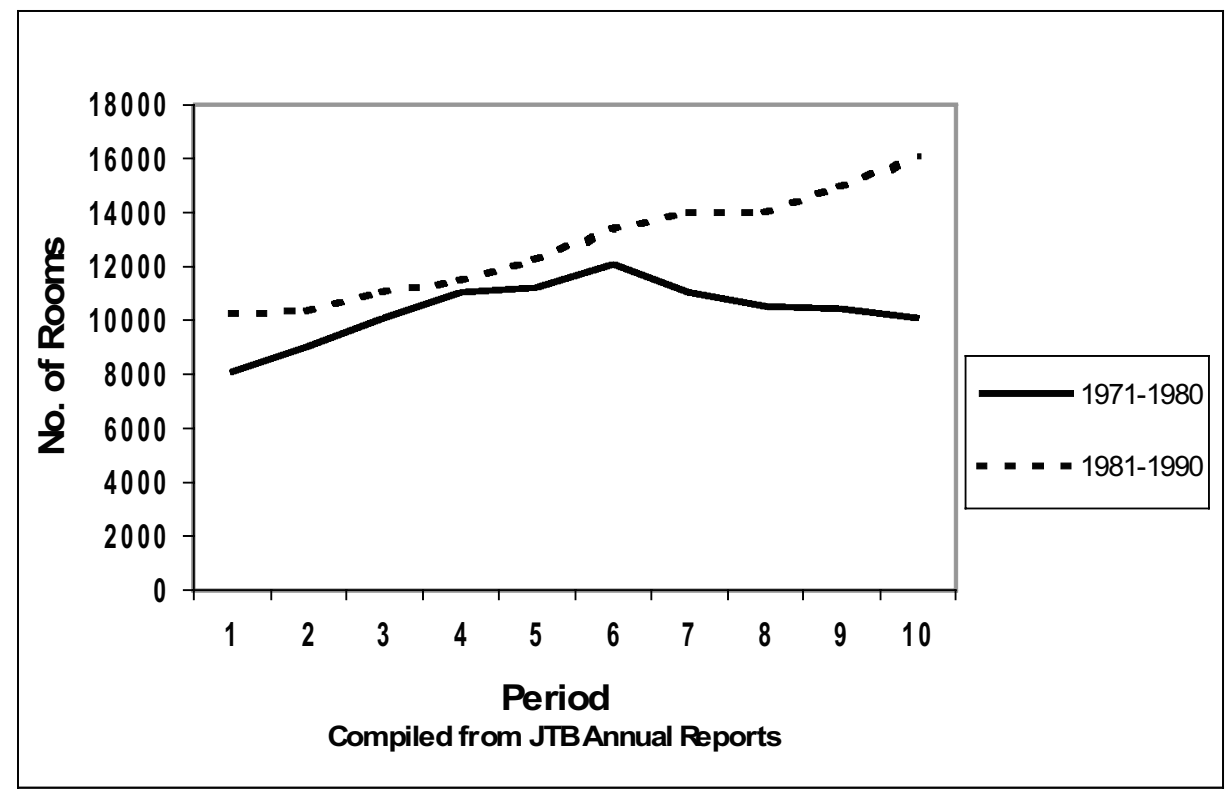

Figure 13 Comparative accommodation facilities 1971-1980 and 1981-1990

Clearly, there are other variables which impact on levels of investment in accommodation such as investor confidence in the country as a whole.

The zero growth recorded in accommodation provision in 1988 can again possibly be attributed to the effects of the hurricane. Overall, between 1981 and 1990 , the growth in accommodation facilities was approximately $57.4 \%$, with an 


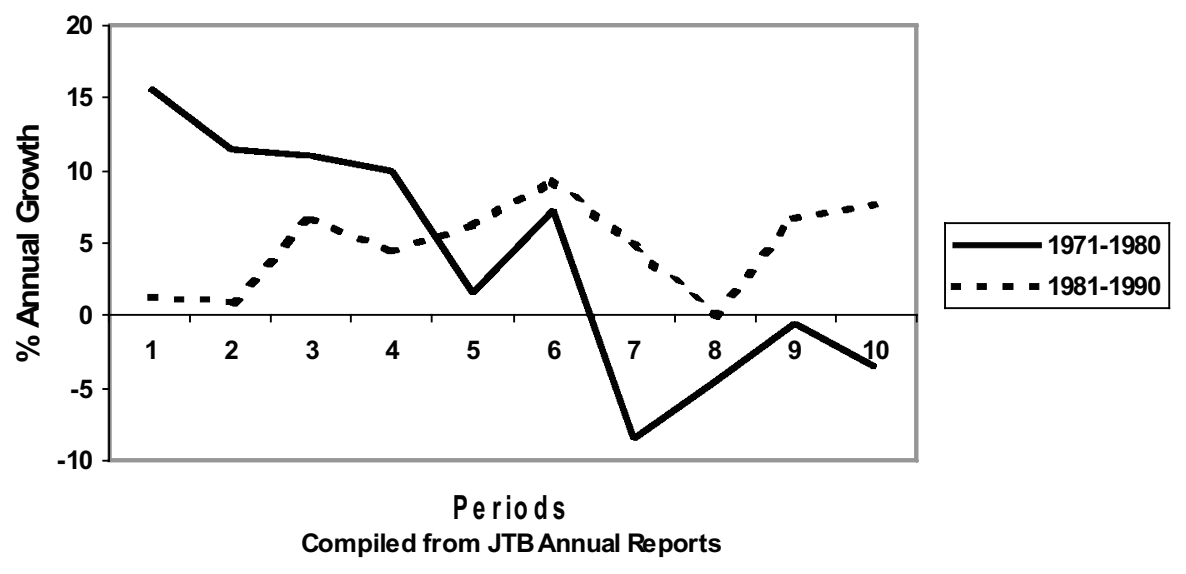

Figure 14 Comparative rates of growth of accommodation facilities 1971-1980 and 1981-1990

average growth rate over the period of $4.8 \%$. Between 1971 and 1980 these figures were $24.2 \%$ and $3.9 \%$ respectively. Figure 13 illustrates the comparison in the number of accommodation facilities and it is interesting to note that the number of rooms between 1971 and 1976 and between 1981 and 1986 closely approximate to each other. However, after 1986 the gap widens considerably. Figure 14 illustrates the comparative rates of growth.

Figure 15 indicates that direct employment figures grew consistently during the 1980s. Indeed, in the 10-year period between 1981 and 1990, direct employment almost doubled. This was in keeping with the increase in accommodation facilities during the period although the rate of growth of employment appears higher than the rate of growth of accommodation facilities particularly between 1981 and 1986. In comparison, during the preceding 10-year period there was only a marginal increase in employment.

As shown in Figure 16, the amounts allocated to the JTB have increased in keeping with the exigencies of the period as was the case in the 1970s. After the gas price demonstrations in 1986 and again after the hurricane in 1988, grants to the JTB increased substantially. In the fiscal year 1988/89, grants to the tourist board reached their highest level. However, when set against government expenditure in general, using IMF figures (1990), the increases are not impressive, rising from $0.2 \%$ in 1980 to $0.4 \%$ in 1982 , and then falling back to $0.1 \%$ under the influence of a general increase in government expenditure, which was, in turn, influenced by high inflation.

In this section it was demonstrated that in terms of all the traditional macro indices of tourism development, the period of the 1980s was much more successful than the period of the 1970s. This is despite the fact that unlike the 1970s, there was no comprehensive policy document which contained government's proposals for the development of the tourism industry. It is being suggested, however, 


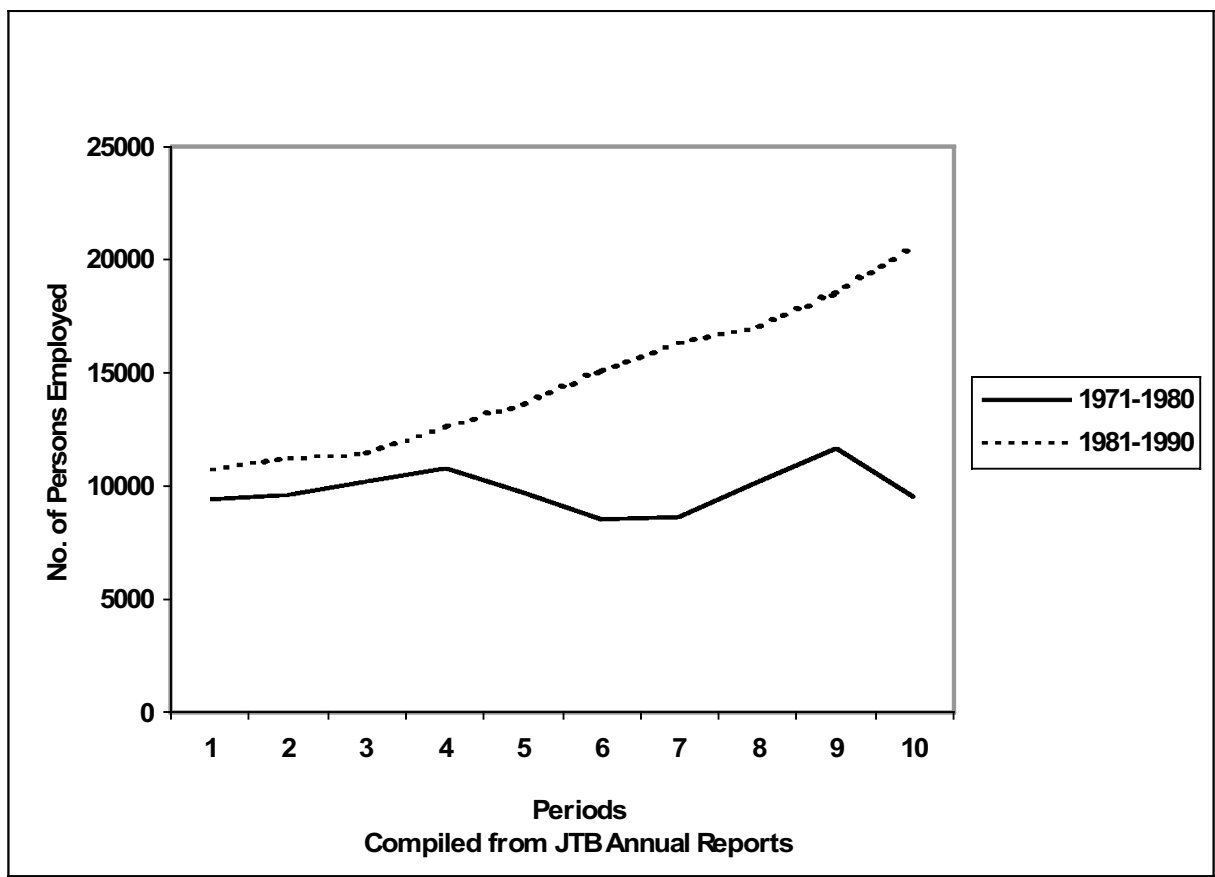

Figure 15 Comparative employment in accommodation sub-sector 1971-1980 and 1981-1990

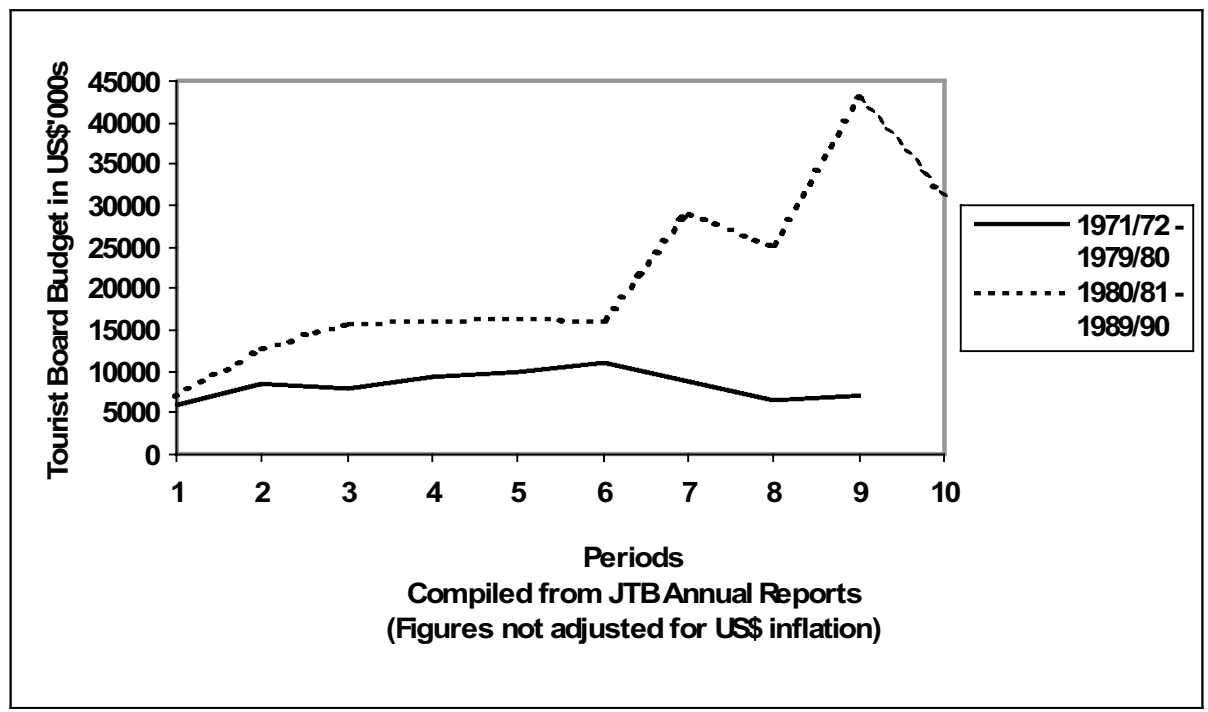

Figure 16 Comparative Tourist Board budgets $1971 / 72$ to $1979 / 80$ and 1980/81 to $1989 / 90$

Figures are on a fiscal year basis from April 1 in one year to March 31 in the following year. In addition figures represent the amounts approved by the government which is not necessarily the same as the amount actually dispensed 
that a factor contributing to the success of the industry was the JLPs deliberate foreign policy of establishing friendly relations with the United States from which most of the island's visitors emanated. Friendship with the United States also gave the country access to monetary assistance (directly through the US government and indirectly through the IMF and World Bank) which had not previously been available to the socialist regime. According to Blomstrom \& Hettne (1984: 116) 'as Reagan's showcase of 'freedom in action' Jamaica cannot be allowed to fail'.

However, the hardships occasioned by structural adjustment policies led the people of Jamaica to believe that the JLP regime was unfeeling, caring only about financial matters and concomitantly ignoring the social well-being of the people. Indeed, speaking retrospectively, Edward Seaga, in his presentation to the Annual Budget Debate in 1993/94, noted that: 'A legacy of the 1970s was the dependency of the individual on the state, a natural outcome of the primacy of the state in socialist doctrine. In contrast, individual enterprise was to be the theme of the 1980s'. The escalation of harassment during the 1980s is, in part, testament to the government's failure to address this necessary social aspect of tourism development.

By 1989, the people of Jamaica had grown weary of the JLPs austerity measures and the party was consequently soundly defeated in the 1989 General Elections. Once again, the PNP assumed power and still forms the government up to the time of writing.

\section{Conclusion}

The paper has sought to trace the role of public policy in tourism development in Jamaica in two distinct periods from 1972 to 1980 and from 1980 to 1989. The analysis was divided into two significant periods. Each period reflected the different politico-economic policies of the two governments which have alternately held the reins of political power over the period. Such an analysis was based on the premise that there exists some correlation between politics, as expressed in public policy, and the development of tourism.

From the outset it was made clear that the paper was descriptive, and not prescriptive in nature. In other words, it was concerned with what happened, how it happened, why it happened and who was responsible. Therefore, those who seek to find recommendations for the way in which public policy should be applied to tourism development will not find these within this paper. Precise causal explanations of the links between public policy and tourism development could not be provided because of the influence of a number of other factors, chief among which are external issues such as the economic climate in the major source markets. Nevertheless, despite these difficulties some important points have emerged.

First, the paper illustrates that tourism public policies are strongly influenced by the ideological thrust of the governing political parties. During the 1970s, when the government declared itself to be socialist, it embraced the economic theory of dependency, and self-reliance was emphasised as an economic strategy. Policies were therefore developed for the tourism industry. These policies were aimed at increasing the local content in the ownership and operation of 
tourism facilities. However, adherence to the political ideology of socialism and its attendant economic philosophy of dependency meant that the government linked the tourism industry to subservience and racial and class conflict at the same time that it admitted the industry's pivotal role in the island's development. The government was therefore caught in a paradoxical situation. This paradoxical situation was reflected in the tourism policies developed by the government and necessarily mitigated against the successful development of the industry during the 1970s.

Second, it demonstrates the danger faced by a tourism dependent, small island state in the 'backyard' of the United States, articulating an ideology and developing public policies which are antithetical to the latter's political philosophy. As a result, the statistics revealed that, compared to the 1980s, the macro indices of tourism development did not perform well under the socialist regime. The 1980s witnessed the introduction of capitalism and this ideology was reflected in the economic policies of the government which focused on the encouragement of foreign investment and the reduction of government involvement in industry. The government's foreign policy of developing friendly relations with the United States impacted positively on the tourism industry.

Finally, in developing countries such as Jamaica, the importance of the tourism industry has meant that, despite the contrasting politico-economic policies of the governing parties, what is common to both governments is that public policies have always played a key role in the industry's development.

\section{Appendix}

Official reports not mentioned in references

\section{Government documents/Parliamentary reports}

Economy \& Production Committee, 1998, Deliberations on the Tourism Sector and Bureaucratic Impediments to Production.

Government of Jamaica, 21 February 1996, National Industrial Policy: A Strategic Plan for Economic Growth and Development, Taking Jamaica into the Twenty-first Century.

Highlights of the Jamaica Labour Party Manifesto, 1997, Taking Charge of our Future.

Honourable Francis Tulloch's contribution to the 1998/99 Budget Debate, 5 May 1998,The Way Forward.

Ministry Paper No. 61, 16 December 1975.

Natural Resources Conservation Authority, September 1997 White Paper, Towards a Beach Policy for Jamaica (A Policy for the Use of the Foreshore and the Floor of the Sea).

Office of the Prime Minister (Tourism), July 1997, Terms of Reference for the Master Plan for Sustainable Tourism Development.

Planning Institute of Jamaica, May 1990, Government of Jamaica National Five Year Plan 1990-1995.

Presentation by the Rt. Hon. Edward Seaga, P.C. M.P., Leader of the Opposition, to the Annual Budget Debate, 1984/85, 1985/86, 1986/87, 1987/88, 1988/89, 1991/92, 1992/ 93, 1993/94, 1994/95, 1995/96, 1996/97, 1997/98, 1998/99.

Presentation by the Rt. Hon. Edward Seaga, P.C. M.P., Leader of the Opposition, to the House of Representatives, 29 April 1999, Why Are We Poor?

Presentation by the Hon. John Junor, Minister of Tourism to Parliament, 30 May 1995.

Statement by the Honourable P.J. Patterson, Minister of Industry, Tourism and Foreign Trade to the Jamaica House of Representatives, 3 December 1975, Tourism: A New Charter: Growth Through Integration. 


\section{Laws of Jamaica}

Hotels (Incentives) Act, 1968.

Resort Cottages (Incentives) Act, 1971.

Natural Resources Conservation Authority Act, 1992.

The Natural Resources Conservation Authority Act, The Natural Resources Conservation (Permits and Licences) Regulations, 1996.

The Tourist Board Act, 1955.

\section{Reports commissioned by government}

Chairman's draft of the report of the Task Force for Tourism, 31 March 1995.

Dunn, L.L. and Dunn, H. (1994) Report on Visitor Harassment and Attitudes to Tourism and Tourists in Negril.

Humes, C.A. (1980) Tourism Sector Study.

McLarty, C. and Associates (1995) Public Sector Modernisation Project: Corporate Strategy, Division of Tourism.

Organization of American States (1994) Economic Analysis of Tourism in Jamaica.

\section{Official publications}

Jamaica Tourist Board (1997) Annual Travel Statistics.

\section{Correspondence}

Any correspondence should be directed to Donna Chambers, Faculty of Leisure and Tourism, Buckinghamshire Chilterns Universty College, High Wycombe, HP13 5BB

\section{References}

Blomstrom, M. and Hettne, B. (1984) Development Theory in Transition. London: Zed Books.

Caribbean Tourism Organization (1994) Study of the relative impact of all-inclusive and conventional resorts (unpublished report). St Michael, Barbados: CTO.

Curry, S. (1992) Economic adjustment policies and the hotel sector in Jamaica. In P. Johnson and B. Thomas(eds) Perspectives on Tourism Policy. London: Mansell Publishing.

Daily Gleaner, October 1972-October 1979, January 1984- November 1989, January 1990December 1998.

EIU (1993) International Tourism Reports 4. London: EIU.

Hall, C.M. (1994) Tourism and Politics: Policy, Power and Place. Chichester: John Wiley \& Sons.

Hall, C. and Jenkins, J. (1995) Tourism and Public Policy. New York: Routledge.

Hayle, C. (1997) The evolution of tourism: The Jamaican experience. Paper presented at the University of the West Indies Centre for Environment and Development workshop, Kingston, Jamaica, 28-31 October 1997.

Henry, B. (1986) Readings in Tourism. Lecture Series in Hospitality Education. Atlanta: Morris Brown College.

Hines, A.G. (1974) National Tourism Plan: Preliminary Analysis and Proposals. Kingston: Ministry of Industry, Commerce and Tourism.

International Monetary Fund (1990) International Financial Statistics, Yearbook 1990. New York: IMF.

Jamaica Tourist Board Annual Reports (1972/73 - 1995/96). Kingston: JTB.

Jamaica Information Service, June 30, 1999. On www at http:/ / www.jis.gov.jm

Kosters, M. (1984) The deficiencies of tourism science without political science: Comment on Richter. Annals of Tourism Research 11, 610-12.

Manley, M. (1974) The Politics of Change. London: André Deutsch. 
Sealey, N. (1982) Tourism in the Caribbean. London: Hodder \& Stoughton.

Sharpley, J. (1981) Economic Management and the IMF in Jamaica 1972-1980. Bergen, Norway: DERAP Working Paper.

Taylor, F. (1993) To Hell with Paradise: A History of the Jamaican Tourist Industry. Pittsburgh: University of Pittsburgh Press. 